\title{
THE ENVIRONMENTAL ASPECT OF COMPANIES AS A DETERMINANT OF STOCK PRICES
}

\author{
Ida Nurcahyanti ${ }^{1}$ \\ Pendidikan Akuntansi FKIP \\ Universitas PGRI Madiun \\ ida_nurcahyanti@gmail.com
}

\author{
Purweni Widhianningrum ${ }^{2}$ \\ Pendidikan Akuntansi FKIP \\ Universitas PGRI Madiun \\ weni.widhi@gmail.com
}

\begin{abstract}
ABSTRAK
Penelitian ini bertujuan untuk mengetahui pengaruh pengungkapan Corporate Social Responsibility yang terdiri dari faktor ekonomi, lingkungan dan sosial terhadap harga saham pada perusahaan yang terdaftar di Bursa Efek Indonesia. Teknik analisis menggunakan regresi berganda. Hasil penelitian ini menunjukkan bahwa aspek ekonomi dan sosial pengungkapan Corporate Social Responsibility tidak mempengaruhi harga saham, sedangkan aspek lingkungan mempengaruhi harga saham. Hasil ini membuktikan bahwa perusahaan yang memiliki kepedulian lingkungan sebagai upaya untuk mengurangi efek pemanasan global, juga dapat meningkatkan respon positif dari para pemangku kepentingan melalui peningkatan harga saham.
\end{abstract}

Kata Kunci : CSR; Ekonomi; Lingkungan; Sosial; Nilai Perusahaan

\section{ABSTRACT}

This study aims to determine the effect of disclosure of Corporate Social Responsibility which is composed of economic, environmental and social to the stock price on the companies listed on the Indonesia Stock Exchange. The analysis technique uses multiple regression. The results of this study indicate that the economic and social aspects of Corporate Social Responsibility disclosure does not affect the stock price, while the environmental aspects affect the stock price. These results prove that companies that have environmental concerns as an effort to reduce the effects of global warming, can also increase the positive response of stakeholders through an increase in stock prices.

Keywords : $\quad$ CSR; Economic; Enviroment; Social; Company value

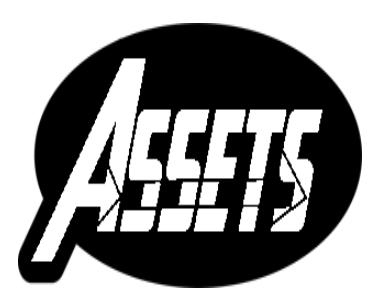

ASSETS

Jurnal Akuntansi dan Pendidikan Vol. 7 No. 2

Hlmn. 105-110

Madiun, Oktober 2017 p-ISSN: 2302-6251 e-ISSN: 2477-4995

Artikel masuk: 28 Februari 2018 Tanggal diterima: 31 Oktober 2018 


\section{INTRODUCTION}

Economic decision making by stakeholders is not only seen from the financial performance of the entity (Cheng, 2011), but also through alternative non-financial information, investors are increasingly used to respond to the market (Hidayat \& Murni, 2009). One of the information used for making investment decisions is information related to corporate social responsibility (CSR) activities. CSR emphasizes that companies must develop ethical business practices that are economically, socially and environmentally sustainable (Harmoni \& Andriyani, 2008). Companies that prioritize sustainability aspects will certainly translate the sustainability principle into the company's strategy and operations, so that the factors that bring profits to the company can be input into the decision making process by investors (Cheng, 2011).

Corporate social responsibility makes the company no longer faced with responsibilities that are based on the single bottom line that is reflected in the financial condition and the stock price alone, but companies must also be based on triple bottom lines that pay attention to social and environmental issues (Badjuri, 2011). Theoretically CSR is the core of business ethics, where a company not only has the obligation of economic and legal obligations to shareholders but the company also has obligations to stakeholders that cannot be separated from the fact that a company cannot live, operate and survive and benefit without assistance from various parties (Yaparto, Frisko, \& Eriandani, 2013).

The results of previous research (Sukanto, 2012: Hamdani, 2014; Wulandari \& Putri, 2014; Amah, Widhianningrum, \& Marwani, 2014; Aji, 2015) prove that the disclosure of Corporate Social Responsibility affects stock prices at companies listed on the Indonesia Stock Exchange. Corporate Social Responsibility disclosed consists of economic, environmental and social aspects. According to Wulandari \& Putri (2014), the more CSR activities undertaken and the increasing value of the rupiah to support CSR activities indicate that the achievement of its profits is increasingly significant. This is very encouraging potential investors in general, especially those that pay attention to the fundamental aspects of the company in investing.

The implementation of social responsibility in Indonesia is regulated in the Indonesian republic Act No. 40 of 2007 concerning limited liability company, Law No. 25 of 2007 concerning Investment related to companies registered in the capital market, and Law No. 32 of 2009 concerning Environmental Protection and Management. However, a number of regulations do not provide specific guidance on how and what information should be reported related to CSR activities, so that CSR information disclosure of some companies in Indonesia is still lacking.

The reporting standard for implementing CSR and internationally known is GRI (Global Reporting Initiative). GRI is an organization that has pioneered the development of CSR disclosures and uses sustainability report frameworks and is committed to continuously improving and implementing throughout the world. Based on GRI guidelines, the company must provide clear information about the impact of its operations on the economic, social and environmental aspects. The economic aspect describes the flow of capital among different stakeholders, and the major economic impacts of the organization in all walks of life. The social aspect describes the organization's impact on the social system on which the organization operates. This aspect is subdivided into 4 (four) categories, namely: labor practices, human rights, society, and product responsibility. While environmental aspects describe the impacts associated with inputs (such as energy and water) and output (such as emissions, enfluenes and wastes), including biodiversity, transportation, and impacts related to products and services, and environmental compliance and costs (GRI G .3, 2013). 
The difference of this study with previous research is that this study uses a sample of companies from all types of industries that publish CSR reports in accordance with GRI standards. Thus the CSR assessment for each company is carried out objectively because it has standard provisions in reporting that are used as a reference for the assessment of each economic, social and environmental aspect. Based on the above considerations, this study aims to analyze the significant influence of the disclosure of Corporate Social Responsibility (which consists of economic, environmental and social aspects) to the stock price of companies listed on the Indonesia Stock Exchange.

\section{METHODS}

The population in this study is all companies listed on the Indonesia Stock Exchange period of 2012, 2013, and 2014. The election in 2012 with the assumption of implementing CSR in Indonesia which is supported by a number of rules such as Law No. 32 of 2009 concerning Environmental Protection and Management can be better implemented in 2012. The analysis technique uses multiple regression.

\section{Table 1. Sample Company Criteria}

\begin{tabular}{clr}
\hline No & \multicolumn{1}{c}{ Description } & Total \\
\hline 1 & Companies listed in the Indonesia Stock Exchange (2012-2014). & 496 \\
\hline 2 & $\begin{array}{l}\text { Companies that do not publish CSR reports consistent with Global } \\
\text { Reporting Inviniative (GRI) standards in the 2012-2014 research period. }\end{array}$ & $(479)$ \\
\hline 3 & $\begin{array}{l}\text { Companies that do not have stock price information (closing price) in the } \\
\text { study period of 2012-2014. }\end{array}$ & $(2)$ \\
\hline Total of Sample Companies & 15 \\
\hline
\end{tabular}

The data in this study comes from secondary data, while data collection techniques in this study is documentation in the form of Corporate Social Responsibility report and annual report, which downloaded by www.idx.co.id. Samples taken by purposive sampling method is to stabilize sample with certain criterion in accordance with intent and purpose of researcher. The criteria used in sampling can be seen in Table 1 and the proxy used in this research is in Table 2. The conceptual framework in this study explains that CSR disclosure (consisting of economic, environmental, and social aspects) affects stock prices as presented in the Figure 1.

Table 2. Definition of Operational Variables

\begin{tabular}{lcc}
\hline \multicolumn{1}{c}{ Variable } & Proxy & Source \\
\hline $\begin{array}{l}\text { Dependen } \\
\text { Variable: } \\
\text { Stock Prices }\end{array}$ & Closing price & Aji \\
& & $(2015) ;$ \\
Amah et \\
Independen
\end{tabular}




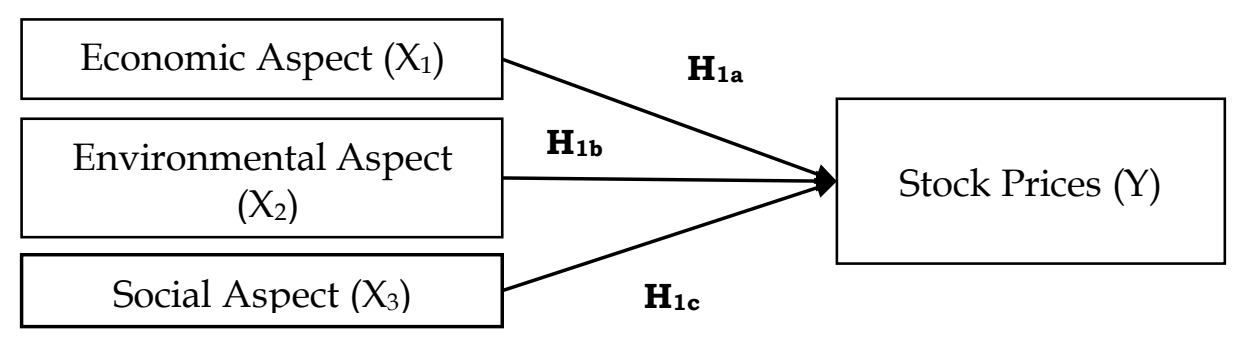

Figure 1. Research Design.

\section{RESULTS AND DISCUSSION}

The results of this study indicate that the residual data in multiple regression models have met the classical assumption test, which consists of normality, multicollinearity, heterocedasticity, and autocorrelation.

Table 3. Multiple Linear Regression Results

\begin{tabular}{|c|c|c|c|c|}
\hline \multirow[b]{2}{*}{ Model } & \multicolumn{2}{|c|}{ Unstandardized Coefficients } & \multirow[b]{2}{*}{$\mathrm{t}$} & \multirow[b]{2}{*}{ Sig. } \\
\hline & B & Std. Error & & \\
\hline 1 (constant) & $-1,717$ & 42,138 & $-0,041$ & 0,968 \\
\hline $\mathrm{x}_{1}$ & 120,415 & 71,762 & 1,678 & 0,101 \\
\hline $\mathrm{x}_{2}$ & 83,566 & 38,433 & 2,174 & 0,036 \\
\hline$X_{a}$ & $-105,859$ & 57,217 & $-1,850$ & 0,072 \\
\hline
\end{tabular}

Based on Table 3, the results of $\mathrm{H}_{1 \text { a }}$ proves that the economic aspects of Corporate Social Responsibility disclosure does not significantly affect the price of shares in companies listed on the Indonesia Stock Exchange. This shows that the presence or absence of economic aspects disclosed in the Corporate Social Responsibility report does not affect the stock price of companies listed on the Indonesia Stock Exchange. This is consistent with previous research conducted by Hidayanyah, Hubeis, and Irwanto (2015) and Eriandani (2010). This indicates if the investor in buying shares in the property sector does not give priority to the assessment on aspects of CSR in the decision of investment. Friedman in Solihin (2011: 6) reveals that the responsibility of the company is to run the business in accordance with the wishes of the owner of the company (owner), usually in the form of making as much money as possible by always considering the basic rules outlined in a society as regulated by law and legislation . The main purpose of a company is the maximization of profit or shareholder value if the leader of the company has a social responsibility to the community at large, considered a manager who acts not in line with the shareholders. While in this study, the analysis conducted on the sample company showed that none of the sample companies consistently disclose the economic aspects of the Corporate Social Responsibility report. So it can be concluded that the company in the disclosure of economic aspects is only used for corporate strategy, this resulted in investors do not consider the economic aspects in investment decision making so it does not affect the stock price of the company.

The results of $\mathrm{H}_{1 \mathrm{~b}}$ prove that the environmental aspects of Corporate Social Responsibility disclosure has a significant effect on stock prices on companies listed on 
the Indonesia Stock Exchange. This indicates that the higher the environmental aspect information disclosed in the Corporate Social Responsibility report, it will increase the company's profit and will increase the company's stock price. This research is consistent with the results of previous research conducted by Aji (2015) and Sukanto (2012). In addition, Law No.40 of 2007 on limited liability companies discloses that companies in the environment of BUMNs and companies whose operations are in contact with natural resource exploitation should set aside three (3\%) for environmental development and partnership activities. However, non-state-owned enterprises and outside industries of natural resource exploitation in its development have implemented social responsibility (Hadi, 2014: 141). While in this study, the analysis conducted on the sample company shows that there is one sample of mining companies that experienced an increase in stock prices in a row from the research period of 2012, 2013 and 2014, are Vale Inco Tbk. In addition to mining companies, there are bank and plantation companies that have increased stock price during the period of research year, such as: Bank BNI Tbk and Astra Agro Lestari Tbk. Based on this, not only companies that exploit the natural resources that care about the environment, but also the environment awareness and care for the environment in the operation of the company's activities, so as to improve corporate image and stakeholder responses that can increase the company's stock price.

The result of $\mathrm{H}_{1 \mathrm{c}}$ proves that social aspect of Corporate Social Responsibility disclosure has no significant effect to stock price at company listed in Indonesia Stock Exchange. This research is consist with previous research conducted by Safira and Riduwan (2015) and Arimbawa and Wirakusuma (2016). According to Pratiwi (2012), the possibility that investors have not considered the social dimension in CSR disclosure as one of the criteria in making investments, so that investors also tend not to pressure the company to disclose CSR in detail in the company's annual report. In addition, the company's understanding of the concept of CSR is still diverse so that the implementation of CSR in Indonesia is highly dependent on the top leadership. That is, if the leadership is only oriented to the interests of shareholder satisfaction (high productivity, large profits, high share value) and personal achievement, then CSR policy is only considered as the achievement of short-term corporate performance (Badjuri, 2011).

\section{CONCLUSION}

The results of this study indicate that in the disclosure of Corporate Social Responsibility, only the environmental aspects affect the stock price, while the economic aspects and social aspects do not affect the stock price. These results prove that companies have environmental concerns as an effort to reduce the effects of global warming that it felt would threaten the sustainability of its business. In addition, this environmental awareness also contributes to a positive response from stakeholders through the increase of stock prices in Indonesia Stock Exchange.

This study has limitations including the observation periods, this study does not separate the types of industries that are directly or indirectly related to natural resources, this study does not use proxy characteristics of the company. Future research are expected to increase the number of samples, use longer periods, use other variables such as company characteristics and separate types of industries that are directly or indirectly related to natural resources to see the effectiveness of implementing CSR regulations in Indonesia.

\section{REFERENCE}


Aji, S. (2015). Rasionalitas Investor di Bursa Efek Indonesia didasarkan pada Pengaruh Pelaksanaan Corporate Social Responsibility (CSR) Terhadap Harga Saham. EBANK, 6 (2), 75-86.

Amah, N., Widhianningrum, P., \& Marwani, H. (2014). Pengaruh Pengungkapan Corporate Social Responsibility Terhadap Harga Saham Dengan Size Perusahaan Sebagai Pemoderasi. Jurnal LPPM , 2 (2), 38-46.

Arimbawa, P., \& Wirakusuma, M. (2016). Pengaruh Pengungkapan informasi Corporate Social Responsibility, Profitabilitas, dan Pembagian Dividen Pada Harga Saham. E-Jurnal Akuntansi Universitas Udayana , 14 (1), 19-33.

Badjuri, A. (2011). Faktor-Faktor Fundamental, Mekanisme Coorporate Governance, Pengungkapan Coorporate Social Responsibility Perusahaan Manufaktur Dan Sumber Daya Alam Di Indonesia. Dinamika Keuangan dan Perbankan , 3 (1), 38-54.

Cheng, M., \& Christiawan, Y. J. (2011). Pengaruh Pengungkapan Corporate Social Responsibility Terhadap Abnormal Return. Jurnal Akuntansi dan Keuangan , 13 (1), 24-36.

Eriandani, R. (2010). Pengaruh Luas Pengungkapan CSR Tehadap Earning Response Coefficient Pada Industry High Profile Yang Terdaftar Di Pasar Modal. AKRUAL , 1 (2), 118-136.

GRI. (2016, March 5). Global Reporting Initiative. Retrieved March 5, 2016, from http://www.globalreporting.org.

Hadi, N. (2014). Corporate Social Responsibility. Yogyakarta: Graha Ilmu.

Hamdani, M. (2014). Hubungan Pengungkapan Corporate Social Responsibility (CSR) Terhadap Kinerja Keuangan dan Harga Saham. Jurnal Organisasi dan Manajemen, 10 (1), 27-36.

Harmoni, A., \& Andriyani, A. (2008). Pengungkapan Corporate Social Responsibility (CSR) Pada Official Website Perusahaan Studi Pada PT. Unilever Indonesia Tbk. Seminar Ilmiah Nasional Komputer dan Sistem Intelijen (KOMMIT) (pp. 475-483). Jakarta: Universitas Gunadharma.

Hidayat, N. N., \& Murni, S. (2009). Pengaruh Pengungkapan Corporate Social Responsibility Terhadap Earnings Response Coeficient Pada Perusahaan High Profile. Jurnal Bisnis dan Akuntansi , 11 (1), 1-18.

Pratiwi, R. (2012). Pengaruh Tingkat Pengungkapan Tanggung Jawab Sosial dan Corporate Social Responsibility dengan Kinerja Keuangan Perusahaan. Jurnal Ilmiah STIE MDP , 2 (1), 1-17.

Safira, Z., \& Riduwan, A. (2015). Pengaruh Corporate Social Responsibility dan kinerja keuangan pada harga saham. Jurnal Ilmu \& Riset Akuntansi , 4 (6), 1-15.

Solihin, I. (2011). Corporate Social Responsibility From Charity To Sustainability. Jakarta: Salemba Empat.

Sukanto, E. (2012). Pengaruh Pengungkapan Corporate Social Responsibility Terhadap Stock Return Pada Perusahaan Yang Berkaitan Dengan Lingkungan Yang Listing Di Bursa Efek Indonesia Tahun 2010 - 2011. Fokus Ekonomi , 7 (2), 45-57.

Wulandari, A., \& Putri, I. (2014). Pengaruh Informasi Laba Akuntansi dan Informasi Corporate Social Responsibility Pada Return Saham. E-Jurnal Akuntansi Universitas Udayana , 7 (2), 462-476.

Yaparto, M., Frisko, D., \& Eriandani, R. (2013). Pengaruh Corporate Social Responsibility Terhadap Kinerja Keuangan Pada Sektor Manufaktur Yang Terdaftar di Bursa Efek Indonesia Periode 2010-2011. Jurnal Ilmiah Mahasiswa Universitas Surabaya , 2 (1), 1-19. 